Egyptian Journal of Aquatic Biology \& Fisheries

Zoology Department, Faculty of Science,

Ain Shams University, Cairo, Egypt.

ISSN $1110-6131$

Vol. 24(3): 145 - 156 (2020)

www.ejabf.journals.ekb.eg

\title{
Species composition, length-weight relationships and condition factor of commercial species grasped by trammel nets and gill nets in the Gulf of Suez, Red Sea, Egypt
}

\author{
Mahmoud A. Saber, Amgad M. Shaaban, Azza A. El ganainy and Hanan M. Osman* \\ National Institute of Oceanography and Fisheries, Suez, Egypt \\ *Corresponding author: hanan_zxcv@yahoo.com
}

\section{ARTICLE INFO \\ Article History: \\ Online: May 2020 \\ Keywords: \\ Isometric growth, \\ Gill net, \\ Trammel net, \\ Gulf of Suez, \\ Condition factor}

Received: March 18, 2020

Accepted: April 29, 2020

\begin{abstract}
Three experimental fishing operations were conducted in the Gulf of Suez during October 2018, January 2019, and September 2019 to analyze the species composition of fishes caught by trammel nets and gill nets. Trammel nets and gill nets are important artisanal fishing gears in the Gulf of Suez. The main catch of the trammel net contained 16 species belonging to 11 families, on the other hand, the catch of gill net was dominated by 4 species belonging to 4 families. Concerning the trammel net, three species constituted about $89.19 \%$ of the total catch (Gerres oyena $33.87 \%$, Siganus rivulatus $25.32 \%$, and Rhabdosargus haffara $20.0 \%$ ). While the catch of gill net composed of 4 species; Siganus rivulatus (51.69\%), Liza carinata $(32.17 \%)$, Gerres oyena (14.14\%), and Diplodus noct $(1.99 \%)$. The results of the length-weight relationships for 9 species revealed that 6 species have isometric growth, two species namely Pomadasys stridens and Liza carinata showed negative allometric growth whereas one species, Siganus rivulatus has positive allometric growth. The mean condition factor, $K$ for 9 fish species in the Gulf of Suez ranged from 1.0 for Liza carinata to 1.6 for Stephanolips diaspros. The provided data can be used as a basis for proper management of the fisheries of these species in the Gulf of Suez.
\end{abstract}

\section{INTRODUCTION}

The Gulf of Suez is the north eastern part of the Red Sea. Suez Bay is the northern part of the Gulf of Suez and provides important nursery areas, feeding sites, spawning grounds and shelter for many fish species (Abd EL-Naby et al, 2018). The small-scale fisheries, Gulf of Suez depend mainly on gill nets and trammel nets with different mesh sizes. Small scale fisheries (SSF) are some of the major economic activities along the Gulf of Suez. There are 711 boats operating along the whole fishing ground of the Gulf of Suez using long lines, trammel nets and gillnets (GAFRD, 2016). Gillnets and trammel nets are widely used in small-scale fisheries because they require little investment in labor and equipment. Trammel nets are sometimes used as a sampling gear because there 
is less mortality associated with them than with gill nets. However, the time required to remove fish from trammel nets is often much more than the time needed to remove fish from gill nets (Hubert et al., 2012).

There are many biological studies on the commercial species that caught by deffernt fishing gears in the Gulf of Suez (El- Ganainy \&Sabrah, 2008, El-Etreby et al., 2013, Sabrah, 2015, El-Ganainy et al., 2018, Osman et al., 2019, Saber \& Gewida 2020). However, there is a little information about the species composition of fishes caught by trammel nets and gill nets in the Gulf of Suez. The Length-weight relationship has an important role in fishery resources management where it is useful for comparing life history, morphological aspects of populations inhabiting different regions, length and age structures and estimating condition factor (Goncalves et al., 1997 and Froese and Pauly, 2012).

Mathematically, length-weight relationship explains the correlation between fish length and fish weight. Hence, it is useful for converting length observations into weight estimates to provide some measure of biomass (Froese, 1998). The information about the length-weight relationships of fish species investigated in our study in the Gulf of Suez is very scarce and incomplete. Relationship between length and weight is required for setting up yield equation (Beverton \& Hold, 1957; Ricker, 1968) and sometimes it may be useful as a character to differentiate "small taxonomic units" (Le Cren, 1951). Thus, the aim of this study is the characterization of trammel nets and gill nets used in the Gulf of Suez and determination of the length-weight relationship for the most common species collected by trammel net and gill net in the Gulf of Suez, Red Sea, Egypt.

\section{MATERIALS AND METHODS}

Fish samples were obtained from an experimental fishing operations conducted by using a small-scale fishing vessel (12 $\mathrm{m}$ length) in the Gulf of Suez (Figure 1). We used a gillnet with mesh size $36 \mathrm{~mm}$ and a trammel net with inner panel mesh size $34 \mathrm{~mm}$. The general characteristics of the trammel net and gill net are shown in Table (1). 


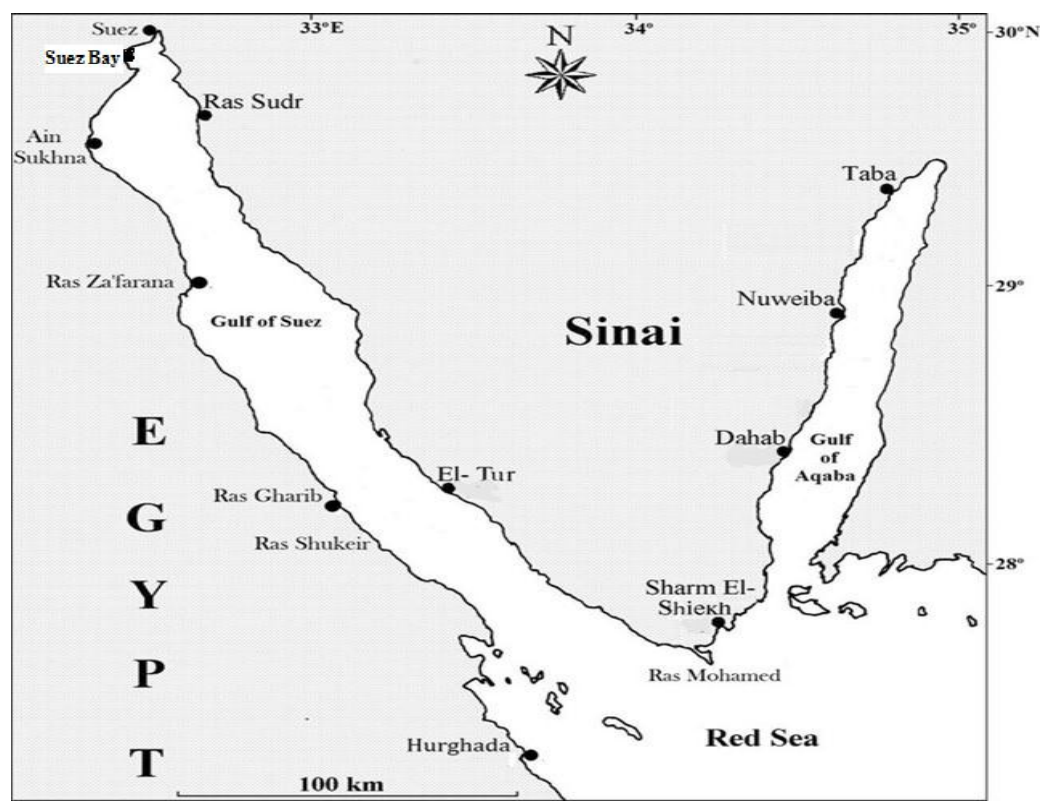

Fig. 1: A map of the study area (The Gulf of Suez).

Table (1): Specifications of the trammel net and gill net used in the Gulf of Suez.

\begin{tabular}{|l|l|l|}
\hline \multicolumn{1}{|c|}{ Gear items } & \multicolumn{1}{|c|}{ Trammel net } & \multicolumn{1}{c|}{ Gill net } \\
\hline Unit length (m) & $35 \mathrm{~m}$ & $50 \mathrm{~m}$ \\
\hline Net depth (m) & $0.95 \mathrm{~m}$ & $1.60 \mathrm{~m}$ \\
\hline Float line materials and diameter & Polyethylene, $5 \mathrm{~mm}$ & Polyethylene, $5 \mathrm{~mm}$ \\
\hline Sinker line materials and diameter & Polyethylene, $6 \mathrm{~mm}$ & Polyethylene, $6 \mathrm{~mm}$ \\
\hline Distance between two floats (cm) & $65 \mathrm{~cm}$ & $115 \mathrm{~cm}$ \\
\hline Distance between two sinkers $(\mathrm{cm})$ & $20 \mathrm{~cm}$ & $33 \mathrm{~cm}$ \\
\hline Total weight of sinkers & $4.5 \mathrm{~kg} / \mathrm{unit}$ & $6 \mathrm{~kg} / \mathrm{unit}$ \\
\hline Mesh Size (mm) & $\begin{array}{l}\text { Inner } 34 \mathrm{~mm} \\
\text { Outer: } 120 \mathrm{~mm}\end{array}$ & $36 \mathrm{~mm}$ \\
\hline Twine materials & Polyamide monofilament & Polyamide monofilament \\
\hline
\end{tabular}

The total catch of the two nets was transported to lab and identified to the species level. The total weight $(\mathrm{g})$ and total lengths $(\mathrm{cm})$ were measured. The relationship between body weight and total length of samples was computed by the equation: 


$$
W=a L^{b},
$$

The parameters $\mathrm{a}$ and $\mathrm{b}$ were obtained by the least-squares method based on logarithms:

$\log \mathrm{W}=\log \mathrm{a}+\mathrm{b} \log \mathrm{L}$, where $\mathrm{W}$ is the total body weight $(\mathrm{g}), \mathrm{L}$ is the total length (cm), $a$ the intercept and $\mathrm{b}$ (the exponent) is the parameter describing growth pattern (Froese, 2006; Thorson \& Reyes, 2013).

Fulton's condition factor $(K)$ was estimated from the relationship $K=100 \mathrm{~W} / \mathrm{L}^{3}$ to assess the fish condition in Gulf of Suez where W is Total Weight in gram, L is Total length in $\mathrm{cm}$ and the factor 100 is used to bring $\mathrm{K}$ close to unity (Le Cren, 1951; Froese, 2006).

\section{RESULTS}

\section{Species composition and catch}

As shown in Table (2), the most dominant species caught by trammel net was Gerres oyena (33.87\%) followed by Siganus rivulatus (25.32\%), Rhabdosargus haffara (20.00\%), Pomadasys stridens (6.29\%), Liza carinata (4.63\%), Parupeneus forsskali (4.09\%), Stephanolepis diaspro (1.95\%), Aluterus Monoceros (1.02\%) and other seven species less than 1\% (Diplodus noct, Scarus harid, Terapon puta, Saurida undosquamis, Synodus variegatus, Mulloides flavolineatu and Upeneus japonicus, Lagocephalus sceleratus) (Fig. 2). While the catch of gill net composed of four species Siganus rivulatus (51.69\%), Liza carinata (32.17\%), Gerres oyena (14.14\%) and Diplodus noct (1.99\%) (Fig. 3).
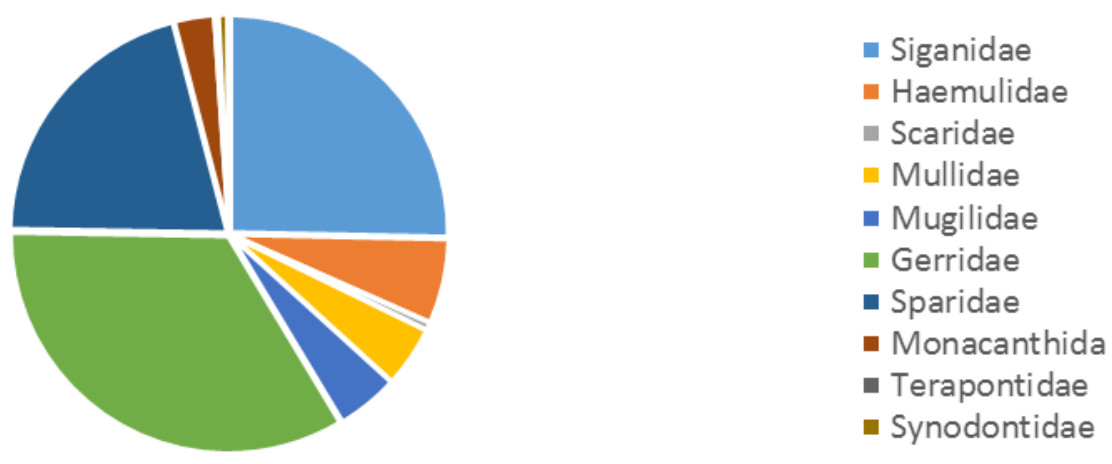

Fig. 2: Catch composition of trammel net 


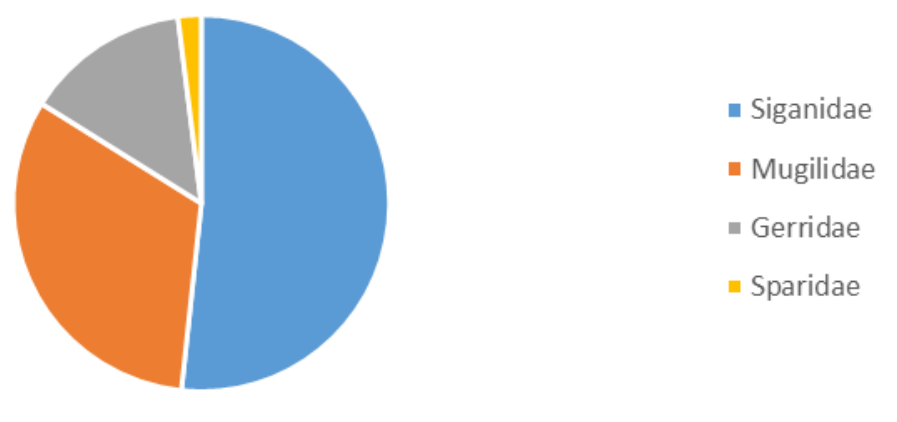

Fig. 3: Catch composition of gill net.

Table (2): Species composition and relative abundance of commercial species caught by trammel nets and gill nets in the Gulf of Suez.

\begin{tabular}{|c|c|c|c|c|c|}
\hline Family & Species & $\begin{array}{l}\text { Number } \\
\text { of } \\
\text { specimens }\end{array}$ & $\begin{array}{c}\text { Total } \\
\text { Length } \\
\text { range }(\mathrm{cm})\end{array}$ & $\begin{array}{l}\text { Total weight } \\
\text { range }(\mathrm{g})\end{array}$ & $\begin{array}{c}\text { Relative } \\
\text { abundance } \\
(\%)\end{array}$ \\
\hline \multicolumn{6}{|c|}{ Trammel net } \\
\hline Siganidae & Siganus rivulatus & 519 & $10.4-24.3$ & $9.5-203$ & 25.3294 \\
\hline Haemulidae & Pomadasys stridens & 129 & $6.3-15.1$ & $3.8-51.6$ & 6.2958 \\
\hline Scaridae & Scarus harid & 12 & $17.1-25.2$ & 98.4-349.5 & 0.5857 \\
\hline \multirow{3}{*}{ Mullidae } & \multirow{3}{*}{$\begin{array}{l}\text { Mulloides flavolineatu } \\
\text { Parupeneus forsskali } \\
\text { Upeneus japonicas }\end{array}$} & 6 & $9.5-15.6$ & $8.9-46.2$ & 0.2928 \\
\hline & & 84 & 8.9-26.4 & $8.3-202.3$ & 4.0996 \\
\hline & & 3 & $9.6-15$ & $14.2-35.0$ & 0.1464 \\
\hline Mugilidae & Liza carinata & 95 & $7.8-18.5$ & $11.2-63.8$ & 4.6364 \\
\hline Gerridae & Gerres oyena & 694 & $10.3-24.6$ & $14.3-160$ & 33.8702 \\
\hline \multirow{2}{*}{ Sparidae } & \multirow{2}{*}{$\begin{array}{l}\text { Diplodus noct } \\
\text { Rhabdosargus haffara }\end{array}$} & 14 & $11.0-16.0$ & $18.6-66.6$ & 0.6833 \\
\hline & & 410 & $8.7-25.4$ & $8.4-251.5$ & 20.0098 \\
\hline \multirow[t]{2}{*}{ Monacanthida } & Stephanolepis diaspro & 40 & $11.2-21.1$ & $17.1-166.4$ & 1.9522 \\
\hline & Aluterus monoceros & 21 & $11.4-21.1$ & $22.4-168.9$ & 1.0249 \\
\hline Terapontidae & Terapon puta & 6 & $5.6-12.6$ & $3.9-23.5$ & 0.2928 \\
\hline \multirow[t]{2}{*}{ Synodontidae } & Saurida undosquamis & 12 & $15.5-22.7$ & $85.2-559.2$ & 0.5857 \\
\hline & Synodus variegatus & 2 & $14.4-27.1$ & $36.3-134.5$ & 0.0976 \\
\hline Tetraodontidae & Lagocephalus sceleratus & 2 & $19-29.6$ & $117.5-355.9$ & 0.0976 \\
\hline \multicolumn{6}{|c|}{ Gill net } \\
\hline Siganidae & Siganus rivulatus & 519 & $10.4-24.3$ & $9.5-203$ & 51.693 \\
\hline Mugilidae & Liza carinata & 323 & $10.9-17.5$ & $14.0-51.0$ & 32.171 \\
\hline Gerridae & Gerres oyena & 142 & $11.3-16.8$ & $19.6-61.8$ & 14.143 \\
\hline Sparidae & Diplodus noct & 20 & $10.8-17.8$ & $17.1-74.3$ & 1.992 \\
\hline
\end{tabular}




\section{The length-weight relationship:}

The length-weight relationship was estimated for the most abundant and important fish species caught with trammel nets and gill net in the Gulf of Suez. The parameters of length-weight relationships ( $a$ and b), standard error (SE), and the coefficient of determination $\left(\mathrm{r}^{2}\right)$ are presented in Table (3). The $b$ values of LWR for 6 species were close to 3 , indicating isometric growth and representing the ideal shape of fish. Two species namely Pomadasys stridens and Liza carinata showed a negative allometric growth of $\mathrm{b}<3.0$ whereas one species Siganus rivulatus had positive allometric growth with $b>3.0$ (Table 4).

Table (3): Parameters of length-weight relationships (LWRs) of investigated fish species collected from the Gulf of Suez $\left(b=\right.$ slope, $a=$ intercept, $r^{2}=$ regression coefficients and $\mathrm{CI}=$ confidence interval.

\begin{tabular}{|c|c|c|c|c|c|c|}
\hline \multirow[b]{2}{*}{ Family } & \multirow[b]{2}{*}{ Species } & \multicolumn{5}{|c|}{ Regression parameter } \\
\hline & & $\mathrm{b}$ & $\bar{a}$ & $\begin{array}{l}95 \% \mathrm{CI} \\
\text { (slope) }\end{array}$ & $\begin{array}{l}95 \% \mathrm{CI} \\
\text { (intercept) }\end{array}$ & $\mathrm{r}^{2}$ \\
\hline \multicolumn{7}{|c|}{ Trammel net } \\
\hline Siganidae & Siganus rivulatus & 3.25 & 0.006 & $3.19-3.32$ & $0.005-0.007$ & 0.97 \\
\hline Haemulidae & Pomadasys stridens & 2.81 & 0.020 & $2.71-2.91$ & $0.016-0.026$ & 0.95 \\
\hline Sparidae & Rhabdosargus haffara & 3.07 & 0.011 & $3.02-3.12$ & $0.010-0.013$ & 0.96 \\
\hline Gerreidae & Gerres oyena & 2.94 & 0.014 & $2.87-3.00$ & $0.012-0.016$ & 0.91 \\
\hline Monacanthidae & Stephanolepis diaspros & 3.06 & 0.013 & $2.84-3.28$ & $0.007-0.024$ & 0.95 \\
\hline Mullidae & parupeneus forsskali & 2.98 & 0.012 & 2.86-3.09 & $0.008-0.017$ & 0.96 \\
\hline \multicolumn{7}{|c|}{ Gill net } \\
\hline Siganidae & Siganus rivulatus & 2.99 & 0.013 & $2.89-3.08$ & $0.010-0.017$ & 0.97 \\
\hline Mugilidae & Liza carinata & 2.55 & 0.034 & $2.44-2.67$ & $0.025-0.047$ & 0.85 \\
\hline Gerreidae & Gerres oyena & 3.08 & 0.010 & $2.93-3.23$ & $0.006-0.014$ & 0.92 \\
\hline
\end{tabular}


Table 4: The estimated values of the length-weight relationship parameters a = intercept and $b=$ slope and the growth pattern of nine species in the Gulf of Suez. NA= Negative Allometric $(b<3), \mathrm{IS}=$ Isometric $(\mathrm{b}=3), \mathrm{PA}=$ Positive Allometric $(b>3)$.

\begin{tabular}{|c|c|c|c|}
\hline Species & Intercept (a) & Slob (b) & Growth pattern \\
\hline \multicolumn{4}{|c|}{ Trammel nets } \\
\hline Siganus rivulatus & 0.006 & 3.25 & PA \\
\hline Pomadasys stridens & 0.020 & 2.81 & NA \\
\hline Rhabdosargus haffara & 0.011 & 3.07 & IS \\
\hline Gerres oyena & 0.014 & 2.94 & IS \\
\hline Stephanolepis diaspros & 0.013 & 3.06 & IS \\
\hline parupeneus forsskali & 0.012 & 2.98 & IS \\
\hline \multicolumn{4}{|c|}{ Gill nets } \\
\hline Siganus rivulatus & 0.013 & 2.99 & IS \\
\hline Liza carinata & 0.034 & 2.55 & NA \\
\hline Gerres oyena & 0.010 & 3.08 & IS \\
\hline
\end{tabular}

\section{Condition factor:}

The condition factor, $K$ for 9 fish species from the Gulf of Suez is presented in Table 5. Concerning trammel net catch, the mean condition factor ranged from 1.1 for Parupeneus forskali to 1.6 for Stephanolips diaspros. While in the gill net, the mean condition factor ranged from 1.0 for Liza carinata to 1.3 for Siganus rivulatus.

Table 5: Condition factor for the most abundant species in trammel and gill net from the Gulf of Suez.

\begin{tabular}{|lccc|}
\hline \multicolumn{3}{c|}{ Trammel Net } \\
\hline Species & Min. K & Max. K & Average. K \\
Siganus rivulatus & 0.7 & 1.7 & 1.3 \\
Pomadasys stridens & 1.0 & 1.6 & 1.3 \\
Rhabdosargus & & & \\
haffara & 1.1 & 1.8 & 1.4 \\
Gerres oyena & 1.0 & 1.5 & 1.2 \\
Stephanolips & & & \\
diaspros & 1.2 & 1.8 & 1.6 \\
Parupeneus forskali & 0.9 & 1.2 & 1.1 \\
\hline & Gill Net & & 1.3 \\
\hline Siganus rivulatus & 1.1 & 1.7 & 1.2 \\
Liza carinata & 0.8 & 1.4 & \\
Gerres oyena & 1.1 & 1.6 & \\
\hline
\end{tabular}




\section{DISCUSSION}

Marine fish communities in tropical regions characteristically have a large number of species and complex interactions as compared to those of the communities in temperate regions. In the present study, the species composition of trammel net was dominated by eleven families (16 species) while the catch of gill net was dominated by four families (4 species).

There were clear differences in fish assemblage composition between the catch of trammel net and gill net. Several species very common in the trammel net catch were absent or very scarce in the gill net catch, thus may be attributed to the trammel net is less selective than the gill net (Erzini et al., 2006).. The present results agree with Martins et al. (1992) and Erzini et al. (2003) who conclude that the greater diversity of trammel net catches compared to other static gear.

Variability in length-weight relationship among species depends on many factors. It may depend on the fishing gear as a mesh size determine the size selectivity. It also may affected by the environmental condition (Forese, 2006). The specimens in this study were collected by trammel and gill net. The value of b normally should lie between 2.5 and 3.5 , our results confirmed this and it also agreed with the other studies on the same species as shown in (Table 6).

An extensive investigation has been made on length-weight relationship of many commercial and economically important species from tropical waters in the world. However, very limited information is available on the length-weight relationship of commercial species in the Gulf of Suez. Furthermore, the results of this work provide useful inputs for fisheries scientists; also it helps in stock assessment models and also spatial- temporal comparisons in the future.

The condition factor is studied for knowing the wellbeing state of fish during its life span (Osman, 2016). The values of condition factor $(\mathrm{K})$ estimated for 9 species ranged from 0.7 to 1.8. The highest mean value of K was 1.6 and recorded for Stephanolips diaspros and the lowest value was 1.0 which recorded for Liza carinata. Barnham and Baxter (1998) proposed that if the $K$ value is 1.00 , the condition of the fish is poor, long and thin. A 1.20 value of $K$ indicates that the fish is of moderate condition and acceptable to many anglers. A good and well-proportioned fish would have a $K$ value that is approximately 1.40. Based on this criterion, the sampled fishes in the Gulf of Suez revealed that two species namely Rhabdosargus haffara and Stephanolepis diaspros are in good condition. Three species are in moderate condition namely Siganus rivulatus, Pomadasys stridens and Gerres oyena. Two species are in poor condition which are Parupeneus forskali and Liza carinata. The variation of $\mathrm{K}$ value may be correlated with sex, maturity stage or state of feeding intensity (Gayanilo \& Pauly 1997; Abowei et al. 2009; Isa et al, 2012). 
Table 6: length- weight relationship parameters for some species in different areas.

\begin{tabular}{|c|c|c|c|c|c|}
\hline Family & Species & Authors & Study area & $\mathrm{a}$ & $\mathrm{b}$ \\
\hline \multirow[t]{3}{*}{ Siganidae } & Siganus rivulatus & Present study & Gulf of Suez & 0.006 & 3.25 \\
\hline & & Belhassan et al, 2017 & Mediterranean sea, Libya & 0.019 & 2.66 \\
\hline & .. & Taskavak\&Bilcenoglu,2001 & Mediterranean sea, Turkey & 0.0004 & 3.20 \\
\hline \multirow[t]{6}{*}{ Mugilidae } & Liza carinata & Present study & Gulf of Suez & 0.034 & 2.55 \\
\hline & & Belhassan et al, 2017 & Mediterranean Sea, Libya & 0.005 & 2.87 \\
\hline & & Taskavak\&Bilcenoglu,2001 & Mediterranean Sea, Turkey & 0.002 & 2.86 \\
\hline & & El-Ganainy et al, 2014 & Suez bay & 0.005 & 2.86 \\
\hline & & Hakimelahi et el, 2010 & Persian Gulf & 0.02 & 2.82 \\
\hline & & Hussain et al, 2010 & Arabian sea & 0.088 & 2.20 \\
\hline \multirow[t]{3}{*}{ Haemulidae } & $\begin{array}{l}\text { Pomadasys } \\
\text { stredinse }\end{array}$ & Present study & Gulf of Suez & 0.02 & 2.81 \\
\hline & & Edelist D. 2014 & Mediterranean Sea, Israel & 0.0112 & 3.07 \\
\hline & & Osman et al 2019 & Gulf of Suez & 0.0074 & 3.02 \\
\hline \multirow[t]{3}{*}{ Sparidae } & R.haffara & Present study & Gulf of Suez & 0.011 & 3.07 \\
\hline & & Mehanna et al, 2001 & Suez bay & 0.017 & 2.94 \\
\hline & & El darwany, 2015 & Lake Timsah & 0.017 & 3.10 \\
\hline \multirow[t]{4}{*}{ Gerreidae } & Gerres oyena & Present study & Gulf of Suez & 0.014 & 2.94 \\
\hline & & El agamy, 1986 & Arabian Gulf & 0.008 & 3.10 \\
\hline & & Kanak et al, 2006 & Okinawa island Japan & 0.003 & 2.87 \\
\hline & & Isa et al, 2012 & kedah, Malaysia & 0.008 & 3.29 \\
\hline \multirow[t]{2}{*}{ Monacanthidae } & S. diaspors & present study & Gulf of Suez & 0.013 & 3.06 \\
\hline & & El ganainy \&Sabrah, 2008 & Gulf of Suez & 0.026 & 2.83 \\
\hline \multirow[t]{3}{*}{ Mullidae } & p. forsskali & Present study & Gulf of Suez & 0.012 & 2.98 \\
\hline & & Mehanna et al, 2018 & Red Sea & 0.007 & 3.16 \\
\hline & & Sabrah, 2015 & Red Sea & 0.021 & 2.80 \\
\hline
\end{tabular}




\section{Aknowledgement}

The authors wish to express their gratitude to fishermen who helped them to collect the fish samples, and they would also like to acknowledge the NIOF for the funding provided for this work.

\section{REFERENCES}

Abd EL-Naby, A. S.; El-Ganainy, A. A; Mohamed,M. A. and El-Mor, M. (2018). Species composition and size structure of experimental beach sein by-catch in eion moussa, north Gulf of Suez, Egypt. Al Azhar Bulletin of Science 29(2): 39-47.

Abowei, A.F.N.; Davies, O.A. and Eli, A. A. (2009). Study of the length-weight relationship and condition factor of five fish species from Nkoro River, Niger Delta, Nigeria. Jou. of Biolo.Scie. 1(3): 94-95.

Barnham, C. and Baxter, A. 1998. Condition Factor, K, for Salmonid Fish. Fisheries Notes, pp. 1-3.

Belhassan, A. M. A.; Ali, R. A. S.; Ali, S. M., and Elmor, M. (2017). Species Composition, Relative Abundance and Length-Weight Relationship of Ten Exotic Fishes from Eastern Libya Mediterranean Sea Coast. Journal of Global Scientific Research 2, 13-23.

Beverton, R.J.H. and Holt, S.J. (1957). on the dynamics of exploited fish populations. Fish. Invest. Ser. 2 Mar. Fish. G.B. Minist. Agric. Fish. Food No.19, 533.

Edelist, D. (2014). New length-weight relationships and Lmax values for fishes from the Southeastern Mediterranean Sea. J. Appl. Ichthyol. 30 : 521-526.

El agamy, A.E. (1986). The fecundity of gerres oyena forskal 1775, (fam. gerreidae) in the qatari waters of the Arabian Gulf. Qatar Univ. Sci. Bull. (1986), 6: 371-388.

El darwany, M.A. (2015). Age, growth and mortality of Rhabdosargus haffara in Lake Timsah, (Suez Canal, Egypt): international J. of Fish. and Aqu. Stu. 3(1): 239243.

El-Ganainy, A. A. and Sabrah, M. M. (2008). Age, Growth, Mortality and Yield per Recruit of the Filefish Stephanolepis diaspros (Fraser-Brunner, 1940) (Pisces: Monacanthidae), in the Gulf of Suez, Egypt. J. Fish. Aqu. Sci., 3 (4): 252-260.

El-Ganainy, A.A. ; Abd El-Rahman F.A.A. ; Rizkalla, W. ; El-Shabaka, H.A. and AboMesalem, M.A. (2014). Age, growth and reproductive biology of the keeled mullet Liza carinata from theSuez Bay, Red Sea, Egypt. Egypt. J. Aquat. Biol. \& Fish., Vol. 18, No. 4: $1-8$.

El Ganainy, A. A. ; Khalil, M. T. ; El Azab, E. B. ; Saber, M. A. and Abd El-Rahman F. A. (2018). Assessment of three nemipterid stocks based on trawl surveys in the Gulf of Suez, Red Sea. Egyptian Journal of Aquatic Research. 44(1):45-49.

El-Etreby S. G.; El Ganainy A. A.; Saber M. A.; El Elwany M. A and El Bokhty, A. E.

(2013). Age, growth and reproduction of the lizard fish Saurida undosquamis from the Gulf of Suez, Red Sea, Egypt. Egypt. J. Aquat. Biol. \& Fish., Vol. 17 No. 3, 2534.

Erzini, K.; Gonc alves, J.M.S.; Bentes, L. ; Lino, P.G.; Ribeiro, J.; Stergiou, K.I., (2003). Quantifying the roles of competing static gears: comparative selectivity of 
longlines and monofilament gill nets in a multi-species fishery of the Algarve (southern Portugal). Sci. Mar. 67, 341-352.

Erzini, K. ; Gonc alves, J.M.S. ; Bentes, L. ; Moutopoulos, D.K. ; Casal, J.A.H.C. ; Soriguer, M.C. ; Puente, E. ; Errazkin, L.A. ; Stergiou, K. I. (2006). Size selectivity of trammel nets in southern European small-scale fisheries. Fish. Res. 79 (1-2), 183-201.

Froese, R. (1998). Length-weight relationships for 18 lessstudied fish species. J. Appl. Ichthyol. 14: 117-118.

Froese, R. (2006). Cube law, condition factor and weight-length relationships: History, meta-analysis and recommendations. Journal of Applied Ichthyology, 22, 241253.

Froese, R. and Pauly, D. (2012). FishBase World Wide Web electronic publication http://www.fishbase.org.

Froese, R.; Thorson, S.J. J. and Reyes, R.B. (2013). A Bayesian approach for estimating length-weight relationships in fishes. J. Appl. Ichthyol. : 1-7.

GAFRD (2016). General Authority for Fish Resources Development) of Ministry of Agriculture. Fishery statistics

Gayanilo, F.C. and Pauly, D. (1997). FAO ICLARM stock assessment tools (FISAT), References Manual, FAO Computerized Information Series (Fisheries) 8, 262.

Goncalves, J. M. S. ; Bentes, L. ; Lino, P. G. ; Ribeiro, J. ; Canario, A. V. M., and Erzini, K. (1997). Weight-length relationships for selected fish species of the small-scale demersal fisheries of the south and southwest coast of Portugal. Fisheries Research, Vol. 30, 253-256.

Hakimelahi, M.; Kamrani, E.; Taghavi Motlagh, S. A.; Ghodrati Shojaei, M. and Vahabnezhad, A. (2010). Growth parameters and mortality rates of Liza klunzingeri in the Iranian waters of the Persian Gulf and Oman Sea, using length frequency data. J. Fish. Sci., 9(1): 87-96.

Hubert, W. A.; Pope, K. L.; and Dettmers, J. M. (2012). "Passive Capture Techniques". Nebraska Cooperative Fish \& Wildlife Research Unit -- Staff Publications. 111.https://digitalcommons.unl.edu/ncfwrustaff/111

Hussain, S. M.; Paperno, R. and Khatoon, Z. (2010). Length-weight relationships of fishes collected from the Korangi-Phitti Creek area (Indus delta, northern Arabian Sea). J. Appl. Ichthyol., 26: 477-480.

Isa, M. M.; Abdul Basri, M. N.; Zawawi, M. Z. M.; Yahya. K. and Nor, S.A. (2012). Length-weight Relationships of Some Important Estuarine Fish Species from Merbok Estuary, Kedah. Jou. of Nat. Scie. Rese. 2(2): 2224-3186.

Kanak, M.K. and Tachihara, K. (2006). Age and growth of Gerres oyena (Forsska ${ }^{\circ}$, 1775) on Okinawa Island, Japan. J. Appl. Ichthyol. 22; 310-313.

Le Cren, C. D. (1951). The length-weight relationship and seasonal cycle in gonad weight and condition in the perch (Perca fluviatilis). J. Anim. Ecol., 20: 201-219.

Martins, R.; Santos, M.N.; Monteiro, C.C. and Paes da Franca, M. D. L. (1992). Contribuic, ao para o estudo da selectividade das redes de emalhar de um pano fundeadas na costa Portuguesa no bi'enio 1990-1991. INIP, Relat. T’ec. Cient., $1-26$. 
Mehanna S. F. (2001). Growth, mortality and yield per recruit of Rhabdosargus haffara (Sparidae) from the Suez Bay. Egypt J Aquat. Biol. \& Fish.; 5(3):31-46.

Mehanna, S.F.; Osman, A.G.; Farrag M. M. and Osman, Y.A.A. (2018). Age and growth of three common species of goatfish exploited by artisanal fishery in Hurghada fishing area, Egypt. j. appl. ichthyol.34; 917-921.

Osman, H. M. (2016). Biological and Fisheries Studies on Barracuda Fish (Family: Sphyraenidae) in the Gulf of Suez. Ph.D. Thesis, Fac. Sci. Suez Canal, Uni. Ismailia, Egypt.

Osman, H. M.; Saber, M. A. and El Ganainy, A. A. (2019) Population structure of the striped piggy Pomadasys stridens in the Gulf of Suez. Egyptian Journal of Aquatic Research 45 (2019) 53-58.

Ricker, W. E. (1968). Methods for assessment of fish production in fresh waters. IBP Handbook No. 3. F. A. Davis, Philadelphia, Pennsylvania. 328 p.

Saber, M.A. and Gewida, A.G.A. (2020) The influence of trammel net fishing on the Rabbit fish (Siganus rivulatus) stocks in Suez Gulf, Red Sea, Egypt. Egypt. J Aquat. Biol. \& Fish. Vol. 24(2): $135-145$.

Sabrah, M. M. (2015). Fisheries biology of the Red Sea goatfish Parupeneus forsskali (Fourmanoir \& Gue'ze', 1976) from the northern Red Sea, Hurghada, Egypt. Egyptian Journal of Aquatic Research. 41, 111-117

Taskavak, E. and Bilcenoglu, M. (2001). Length weight relationships for 18 lessepsian (Red Sea) immigrant fish species from the eastern Mediterranean coast of turkey. J. Mar.Biol. Ass.U. 81.; 895-896 